\title{
Forest Succession Following a Spruce Budworm Outbreak in Minnesota
}

\author{
by
}

\author{
Harold O. Batzer and Michael P. Popp ${ }^{1}$
}

\begin{abstract}
Plots in 24 spruce-fir stands in northeastern Minnesota studied throughout the period 1957 to 1962 at the time of a spruce budworm outbreak were remeasured in 1979. Composition of the overstory changed from an average of $79 \%$ of the basal area in host species before to $31 \%$ after the budworm outbreak. Twelve percent of the stands showed growth in nonhost species that more than offset the loss in balsam fir and white spruce. The understory was minimally stocked with balsam fir in two-thirds of the stands. Only $4 \%$ of the regeneration was spruce. Even so, some wellestablished white spruce seedlings were found in twothirds of the stands. Red maple was the most abundant hardwood invader. Raspberry, hazel and mountain maple were the principal shrub species limiting balsam fir reproduction. Shrubs were most abundant in stands where balsam fir mortality had exceeded $80 \%$. Half of the stands had seedlings that originated both before and after the outbreak; $45 \%$ had seedlings that originated only after the outbreak; and $5 \%$ had seedlings that originated only before the outbreak. Stands having moderate mixture of nonhost species in the overstory prior to the budworm outbreak had the most balsam fir regeneration. This resulted from seed produced by surviving balsam fir trees after the outbreak.
\end{abstract}

Key words: Choristoneura fumiferana, Abies balsamea, Balsam fir, spruce-fir, shrubs

\section{Résumé}

Des places-échantillons établies entre 1957 et 1962 dans 24 peuplements composés d'épinettes et de sapins lors d'une attaque de la tordeuse des bourgeons de l'épinette au nord-ouest du Minnesota ont été remesurés en 1979. La composition de l'étage dominant a changé chez les essences susceptibles aux attaques de la tordeuse, passant d'une surface terrière de $79 \%$ à $31 \%$ après l'épidémie. Dans $12 \%$ des peuplements, la croissance des essences non susceptibles a plus que contrebalancé la perte chez le sapin baumier et l'épinette blanche. Le sapin baumier reboisait l'étage inférieur d'une façon minimale dans les deux tiers des peuplements. Seulement $4 \%$ de la régénération était constituée d'épinette blanche même si des semis de cette dernière essence étaient bein établis dans les deux tiers des peuplements. L'érable rouge était l'essence feuillue la plus envahissante. Les framboisiers, les noisetiers et l'érable à épis étaient les principaux arbustes limitant la régénération du sapin baumier. Les arbustes abondaient davantage lorsqu'il y avait un taux de mortalité du sapin baumier supérieur à $80 \%$. Dans la moitié des peuplements, les semis orginaient soit avant ou après l'épidémie; dans $45 \%$ des cas, après l'épidémie seulement; et dans $5 \%$ des cas, avant l'épidémie seulement. Les peuplements possédant un pourcentage modéré d'essences non susceptibles à l'étage dominant ont donné le meilleur taux de régénération en sapin baumier puisque les arbres de cette essence ont survécu davantage à l'épidémie permettant ainsi la production de graines.
The impact of major attacks of the spruce budworm, Choristoneura fumiferana (Clem.), on the standing volume of mature and immature balsam fir (Abies balsamea (L.) Mill.) and spruce (Picea spp.) in eastern North America has been widely reported and recently reviewed (MacLean 1980). However, more information is needed on changes in stocking and composition of stands following such major disturbances. Forest

IUSDA Forest Service, North Central Forest Experiment Station, St. Paul, MN 55108. This research was funded by the Canada/United States Spruce Budworms Program - East. succession is of great interest ecologically and can have important economic and social consequences. Succession can affect forest management decisions through changes in composition of tree species and stocking of the new stands. Food and habitat for wildlife, forest fire spread (Sando and Haines 1972), and precipitation run-off may be temporarily affected (Halvey and Tiedemann 1978). Recreational opportunity may be affected through vegetational preferences for campsites, vistas, and other amenities. All of these influences are affected by regional differences. 
Early research on spruce budworm infestations showed that much of the balsam fir died following attack by the budworm while most of the spruce survived. As a result it was hypothesized that subsequent stands would have greater percentages of spruce (Craighead 1924). Conversely, it was contended that the percentage of balsam fir in subsequent stands would increase because of the competitive advantage of balsam fir seedlings (Swaine 1933, DeGryse 1944). Ghent (1958) found that balsam fir flower production and seedling establishment ended with the onset of heavy defoliation. He and Vincent (1962) reported that most balsam fir seedlings predated spruce budworm outbreaks. New seedlings may be established in stands where seed trees survived the budworm outbreak (Fye and Thomas 1963). They reported that advance growth on plots where the overstory was killed had begun to produce seeds about 15 years later. Prebble (1949) reported shrub invasion provided intense competition for conifer seedlings.

Ghent et al. (1957) suggested that the widely divergent theories on the role of the budworm in forest succession following spruce budworm devastation, result from the apparent regional influence on succession. Therefore, because there was a paucity of such information from the Lake States, we remeasured plots in 1979 from seven spruce-fir stands first measured in 1957 and 17 stands established in 1960. These stands were originally infested in 1956 and studied to assess mortality and growth loss resulting from the defoliation to 1963 , one year after the outbreak subsided (Batzer 1969 , 1973). The stands are on the Superior National Forest of northeastern Minnesota, where balsam fir regenerates most aggressively for the state, (Bakuzis and Hansen 1965), yet they border the Canadian zone where reproduction is suboptimal for this tree species (Candy 1951).

\section{Methods}

Twenty-two of 23 stands from the former study and two initially measured but not visited in the interim, all within 50 miles of Ely, Minnesota, were remeasured during the summer of 1979,22 years after the first plots were measured. One logged stand was omitted. A 0.2 ha circular plot was sampled from each of seven stands from the 1957 study and one circular .06 to 0.08 ha plot was sampled form each of 17 stands from the 1960 study. Problems of precision and contagion identified by Ghent (1963) were taken into consideration in sampling design. Trees greater than $1.5 \mathrm{~cm}$ in diameter at breast height $(\mathrm{dbh})$ were tallied to the nearest $0.1 \mathrm{~cm}$ at both measurement times. During remeasurement trees smaller than $1.5 \mathrm{~cm}$ dbh were tallied on $104-\mathrm{m}^{2}$ quadrats randomly chosen within the center $20 \times 20$-m-square of each plot. Within these quadrats trees were tallied by 10 height classes measuring $15 \mathrm{~cm}$ each between ground level and $46 \mathrm{~cm}$ and thereafter every $30 \mathrm{~cm}$ to a height of $2.6 \mathrm{~m}$, as described by Ghent et al. (1957). A light-weight sectional pole on which the class limits were marked was used to determine height classes. Trees shorter than $2.6 \mathrm{~m}$ but greater than $1.5 \mathrm{~cm} \mathrm{dbh}$ were included in the circular plot tally. The five balsam fir seedlings nearest the northwest corner of the 4- $\mathrm{m}^{2}$ quadrat closest to the plot center were cut at ground level and a cross section taken to the laboratory for age determination. Two of the 10 quadrats were randomly chosen for additional tallies of shrubs by species and diameter classes; diameters were measured at $5 \mathrm{~cm}$ above ground level to avoid most of the basal flare.

\section{Results}

\section{Overstory}

Composition of the present overstory was compared with that previously observed at the beginning of the budworm outbreak and immediately after the collapse in 1962. Breastheight ages of the stands at the onset of the budworm outbreak ranged from 27 to 70 and site index for balsam fir ranged from 12 to $18 \mathrm{~m}$ at age 50 (Table 1). Average basal area of balsam fir and white spruce (Picea glauca (Moench) Voss) decreased from $19.3 \mathrm{~m}^{2}$ per ha in 1957 to 11.9 in 1962 to 4.7 in 1979; average number of fir and spruce was reduced from 1124 to 676 to 205 for the same times. It was apparent that tree mortality continued beyond the end of the outbreak. Basal area of species other than balsam fir and white spruce doubled from $5.1 \mathrm{~m}^{2}$ in 1957 to $10.6 \mathrm{~m}^{2}$ per ha in 1979 and their numbers increased from 173 to 281 . The basal area of host species comprised 79,68 , and $31 \%$ in 1957,1962 , and 1979 , respectively. The net effect was to convert the overstory to an earlier successional stage in which aspen (Populus tremuloides Michx.) and white birch (Betula papyrifera Marsh.) predominate. Baskerville (1975) suggests that the less tolerant species may be "rescued" by the severe thinning of the balsam fir resulting from spruce budworm defoliation. However, in the present study, growth of nonhost species offset the loss in host species basal area in only $12 \%$ of the stands.

Table 1. Average stand statistics for host and nonhost trees (greater than $9.0 \mathrm{~cm} \mathrm{dbh}$ ) in 1957 or 1960,1962 and 1979.

\begin{tabular}{|c|c|c|c|c|c|c|}
\hline \multirow{2}{*}{$\begin{array}{l}\text { Species and stand } \\
\text { characteristics }\end{array}$} & \multicolumn{2}{|c|}{1957 or 1960} & \multicolumn{2}{|c|}{1962} & \multicolumn{2}{|c|}{1979} \\
\hline & Ave. & $\mathrm{SE}^{1}$ & Ave. & SE & Ave. & SE \\
\hline \multicolumn{7}{|c|}{ Host (balsam fir and white spruce) } \\
\hline Number/ha & 1124.3 & 107.1 & 676.5 & 93.5 & 204.8 & 33.2 \\
\hline Basal area, $\mathrm{m}^{2} / \mathrm{ha}$ & 19.3 & 1.2 & 11.9 & 1.3 & 4.7 & 0.7 \\
\hline BA of stand $(\%)$ & 79 & & 68 & & 31 & \\
\hline Site index for balsam fir $^{2}$ & 15.5 & 0.3 & & & & \\
\hline Breast-height age for balsam fir & 44 & 2.1 & & & & \\
\hline \multicolumn{7}{|l|}{ Nonhost (other species) } \\
\hline Number/ha & 173.0 & 27.2 & 208.6 & 57.7 & 281.0 & 52.8 \\
\hline Basal area, $\mathrm{m}^{2} /$ ha & 5.1 & 0.8 & 5.5 & 1.3 & 10.6 & 1.7 \\
\hline BA of stand $(\%)$ & 21 & & 32 & & 69 & \\
\hline \multicolumn{7}{|l|}{ Total } \\
\hline Number/ha & 1297.3 & & 885.1 & & 485.8 & \\
\hline Basal area, $\mathrm{m}^{2} /$ ha & 24.4 & & 17.4 & & 15.3 & \\
\hline BA of stand $(\%)$ & 100 & & 100 & & 100 & \\
\hline
\end{tabular}

istandard error

OHt. meters at age 50 (Gevorkiantz 1956) 
Table 2. Average amount of regeneration present in stands in 1979, 23 years after the spruce budworm infestation began, by species, size, and stocking percent.

\begin{tabular}{|c|c|c|c|c|c|}
\hline \multirow[b]{2}{*}{ Species } & \multirow[b]{2}{*}{$\begin{array}{l}\text { Percent stands with } \\
\text { regeneration }\end{array}$} & \multicolumn{3}{|c|}{ No. of stems/ha ${ }^{1}$} & \multirow[b]{2}{*}{$\begin{array}{c}\text { percent } \\
\text { stocking }\end{array}$} \\
\hline & & $\begin{array}{l}\text { Up to } 2.6 \mathrm{~m} \text { tall } \\
\text { and }<1.5 \mathrm{~cm} \mathrm{dbh}\end{array}$ & $\begin{array}{l}\text { Between } 1.5 \text { and } \\
<9.0 \mathrm{~cm} \mathrm{dbh}\end{array}$ & Total & \\
\hline Balsam fir & 96 & 8670 & 1261 & 9931 & 63 \\
\hline White spruce & 66 & 695 & 15 & 710 & 20 \\
\hline Red maple & 42 & 4767 & 268 & 5135 & 50 \\
\hline White birch & 88 & 847 & 411 & 1258 & 27 \\
\hline Aspen & 54 & 1330 & 558 & 1888 & 29 \\
\hline
\end{tabular}

'Excluding stands with no regeneration.

2Percent of $4-\mathrm{m}^{2}$ quadrats having one or more stems $<1.5 \mathrm{~cm} \mathrm{dbh}$

\section{Understory}

The present understory, rather than the overstory portends future stands. The basal area in all species between $1.5 \mathrm{~cm}$ and $9.0 \mathrm{~cm}$ dbh averaged only $2.5 \mathrm{~m}^{2}$ per ha in 1979 , but the number of stems averaged 2073 per ha. Of these, $58 \%$ were balsam fir, $41 \%$ were nonhost species, and less than $1 \%$ were white spruce. Indications are that balsam fir will again be the most common species in future stands (Table 2).

Ninety-six percent of the stands had some balsam fir regeneration; $92 \%$ had 1000 or more trees per ha, $75 \%$ had 2500 or more trees per ha; $63 \%$ had minimally acceptable numbers (more than 3000 trees per ha under $1.5 \mathrm{~cm}$ dbh in an approximately $2-\mathrm{m}$ spacing, or more than $60 \%$ of quadrats stocked with one or more trees 1.5 to $9.0 \mathrm{~cm} \mathrm{dbh}$ ); $58 \%$ had 5000 or more; and $21 \%$ had 10000 or more. Average amount of regeneration present in stands in 1979 by species ranged from a low of 710 per ha for white spruce to 9931 for balsam fir, the most abundant species (Table 2). About one-third of the balsam fir seedlings were less than $15 \mathrm{~cm}$ tall and averaged 2500 trees per ha while number of trees per ha in the taller height classes diminished with increases in height (Figure 1). Spruce seedlings were present in only $66 \%$ of the stands; however, they were well established, those under $1.5 \mathrm{~cm} \mathrm{dbh}$ averaging $41 \mathrm{~cm}$ in height.

\section{Shrubs}

Shrub measurements were not taken prior to the budworm infestation, so species abundance comparisons can only be made relative to each other in 1979. As shown in the following tabulation, Rubus sp. was by far the most abundant:

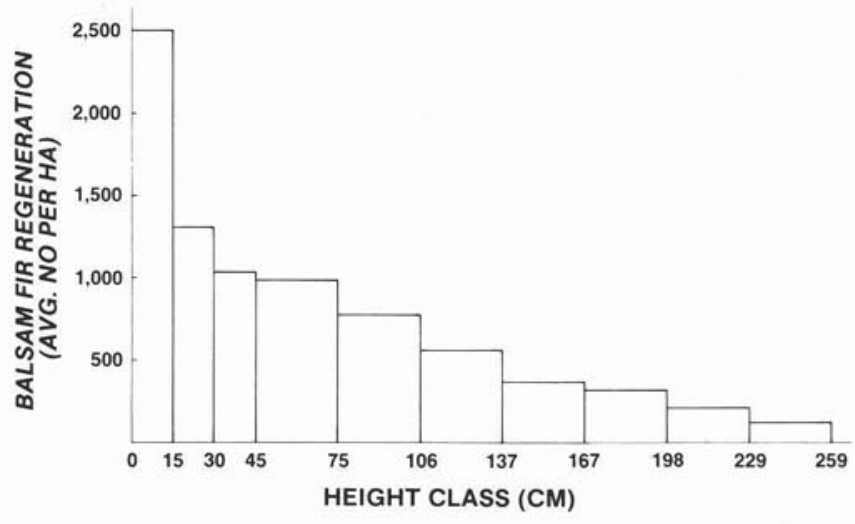

Figure 1. Frequency distribution of balsam fir regeneration by height class in 1979.
Shrub species

Rubus sp.

Corylus cornuta Marsh.

Acer spicatum Lam.

Cornus rugosa Lam.

Diervilla lonicera Mill.

Lonicera sp.

Viburnum Rafinesquianum affine

$$
\text { (Bush) House }
$$

Prunus sp.

Rosa sp.

Ribes $s p$.

Amelanchier sp.

Alnus crispa (Ait.) Pursh

Sambucus canadensis L.

Pyrus americana (Marsh.) DC.
Stems (av. no./ha)

27129

15340

9583

1235

1184

1082

823

771

721

465

413

205

52

52
The three most abundant shrub species in this study were also among the top three reported by Ghent et al. (1957). Shrub density varied inversely with overstory density of the current stands - the greatest number of shrubs occurred in stands with basal areas less than $10 \mathrm{~m}^{2}$ per ha (Figure 2). Balsam fir regeneration was most abundant when shrub density was less than 10000 stems per ha (Figure 3).

\section{Regeneration Related to Stand Characteristics}

Several stand characteristics were examined for relationships to the 1979 regeneration population. Site index for balsam fir was found not to be significantly related to balsam fir regeneration. Pre-outbreak density of balsam fir was also not significantly related to the abundance of balsam fir seedlings. Similarily, the pre-outbreak density of spruce had little bearing on post-outbreak numbers of spruce seedlings. The same relationships held for aspen overstory compared with aspen regeneration and for red maple overstory compared with red maple regeneration.

Regeneration numbers were compared with the following change ratio formula:

$$
\mathrm{CR}=\frac{\text { Present BA }- \text { Pre-outbreak BA }}{\text { Pre-outbreak BA }}
$$

Values are negative where basal area decreases. Low values indicate substantial change in the stands resulting primarily from balsam fir overstory mortality while values approaching 0.0 indicate little change between the two periods. Change ratios above 0 indicate that growth more than offset mortality.

When change ratios were determined for total basal area of all species, only about 2000 balsam fir seedlings per ha occurred below -0.08 but significantly more $(6000$ to 9000 per ha) occurred at higher change ratios. Where change ratios were low, a result of high balsam fir mortality, competition came from the shrub layer (Figure 4 ). Change ratios calcu- 


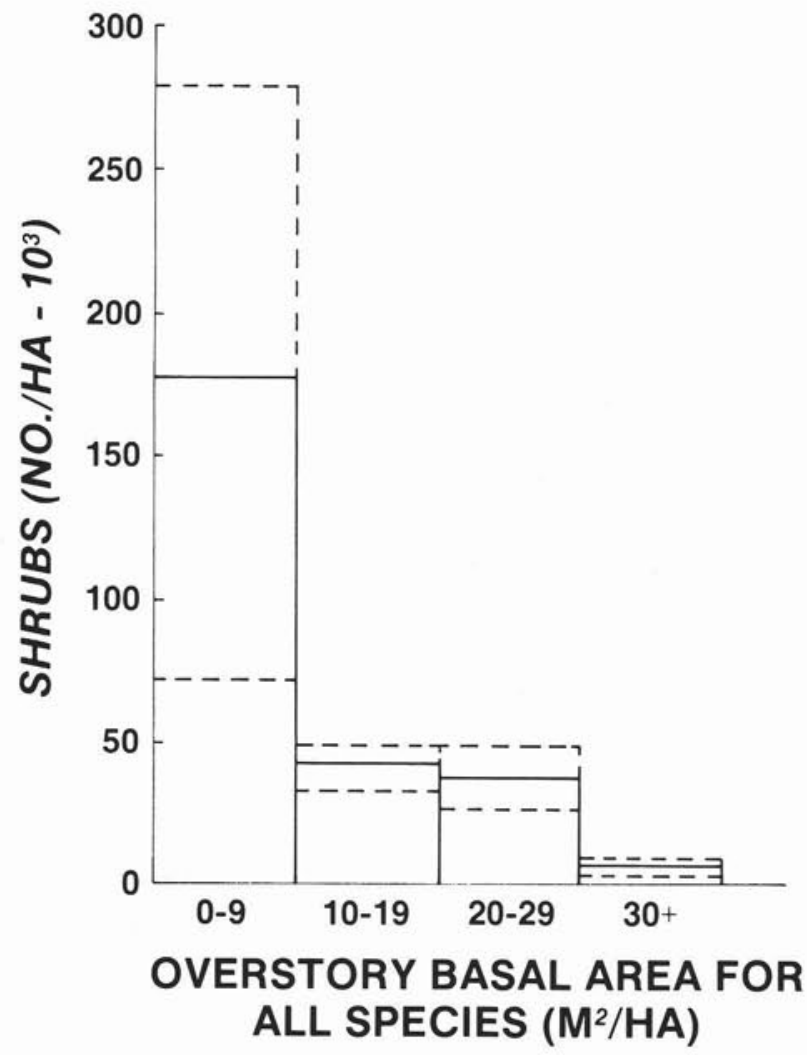

Figure 2. Average number of shurbs per ha by basal area class for all species in 1979. Dashed lines indicate limits of one standard error of the mean.

lated for the host species (balsam fir and spruce) showed no apparent relation to the amount of regeneration but change in stand basal area of host species affected height of balsam fir regeneration. The more open stands had significantly taller seedlings (Figure 5).

Stands considered minimally stocked with balsam fir regeneration had a moderate percentage of basal area in nonhost species $(26 \pm 4 \%)$ prior to budworm attack. Stands understocked with balsam fir regeneration averaged $12 \pm 4 \%$ basal area in nonhost species prior to the outbreak. When prior nonhost basal area was $30-45 \%$, balsam fir regeneration numbered $11,270 \pm 4,250$. However, where nonhost basal area exceeded $45 \%$, fir regeneration, though adequate, dropped to $6,620 \pm 1,850$ per ha because of shading. One explanation for finding adequate balsam fir regeneration in situations with higher nonhost basal area prior to the outbreaks is that mixed stands generally suffer less balsam fir mortality from budworm attack (Batzer and Hastings 1981). Consequently balsam fir survivors contributed seed after the outbreak for restocking.

Stands more than 50 years old at the time of budworm attack averaged $3100 \pm 1340$ stems per ha of balsam fir regeneration, while younger stands averaged $7370 \pm 1370$ stems. Budworm mortality in these older stands was not significantly different from that in the younger stands.

Another response associated with changes in stand basal area after the budworm attack is the abundant hardwood regeneration. Where white birch exceeded 2500 stems per ha and red maple exceeded 8000 stems per ha the change ratio in host species was less than -0.8 .

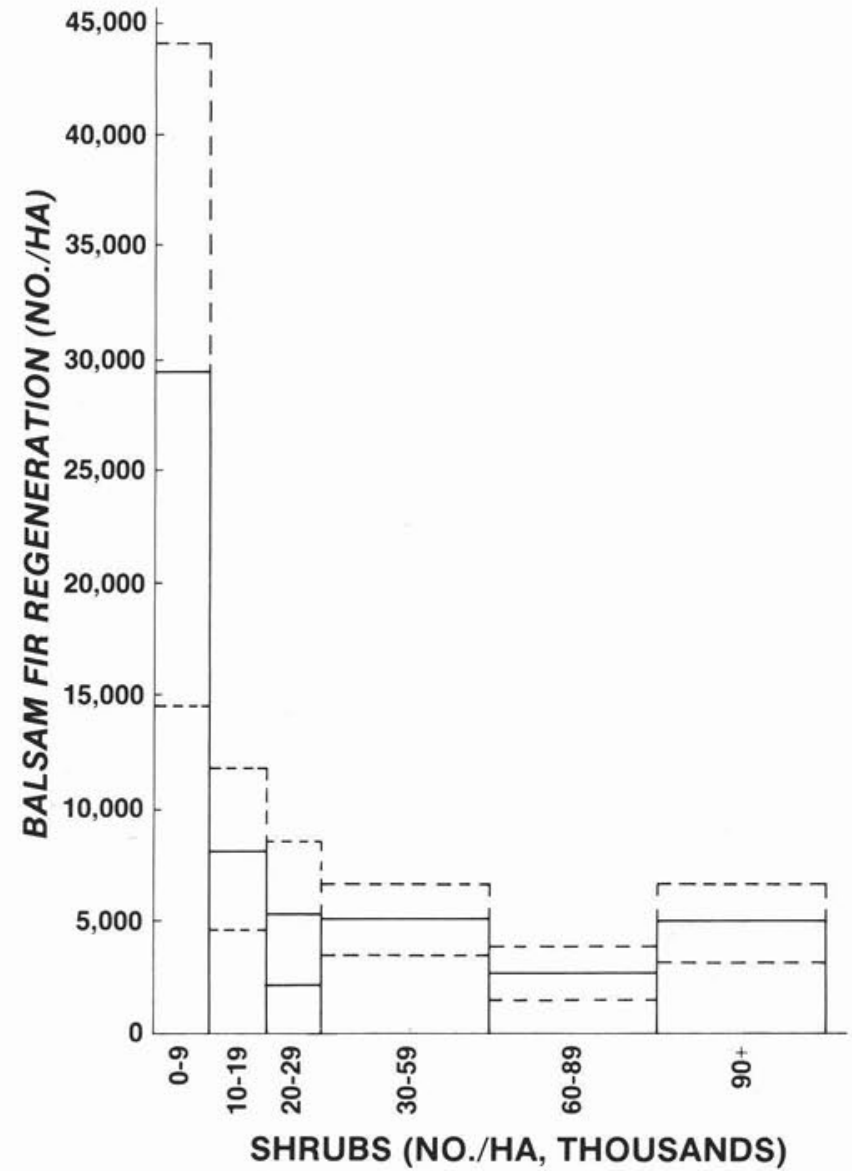

Figure 3. Balsam fir regeneration $<9.0 \mathrm{~cm}$ dbh related to number of shrubs per ha. Dashed lines indicate limits of one standard error of the mean.

\section{Balsam Fir Seedling Origin}

Seedling ages estimated from ring counts at ground level were pooled for all stands. Since nearly equal numbers of seedlings were sampled from each plot the data are based on numbers for the whole sample. The largest number of seedlings were between ages 11 and 17 and became established between 1962 and 1968 with numbers trailing off earlier and later (Figure 6). There was a lag of 6 to 12 years from the time of first defoliation before seedling establishment peaked. Using seedling age 19 (1960) to separate time before from after the budworm outbreak, $5 \%$ of the stands had seedlings originating only before the outbreak; the remaining stands were about equally divided between those having seedlings originating both before and after the outbreak and those with only post-outbreak seedlings. Those stands having seedlings originating before and after the outbreak had higher average numbers of seedlings (Table 3 ).

\section{Conclusion and Discussion}

Although climate, soils, competition, silvics, and spruce budworm outbreaks will vary between regions, certain inferences may be drawn from this study for northeastern Minnesota. Minimally acceptable stocking of balsam fir 23 years after a major spruce budworm outbreak occurred in over two-thirds of the stands studied. Neither site index of balsam fir nor pre-outbreak density of overstory balsam fir, white 


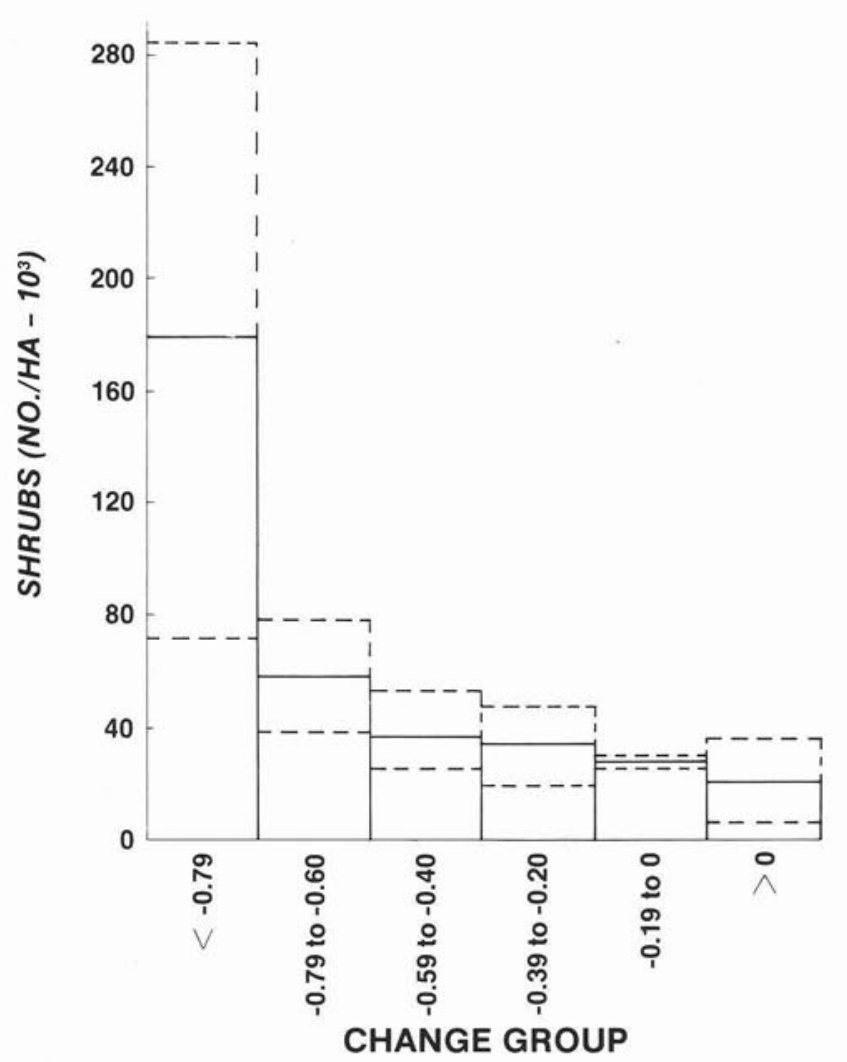

Figure 4. Average number of shrubs per ha by overstory change group for basal area all species 1979 ba - 1957 ba (e.g. a 1957 ba

value of $<-.79$ indicates the greatest reduction in overstory stocking aiter the budworm outbreak). Dashed lines indicate limits of one standard error of the mean.

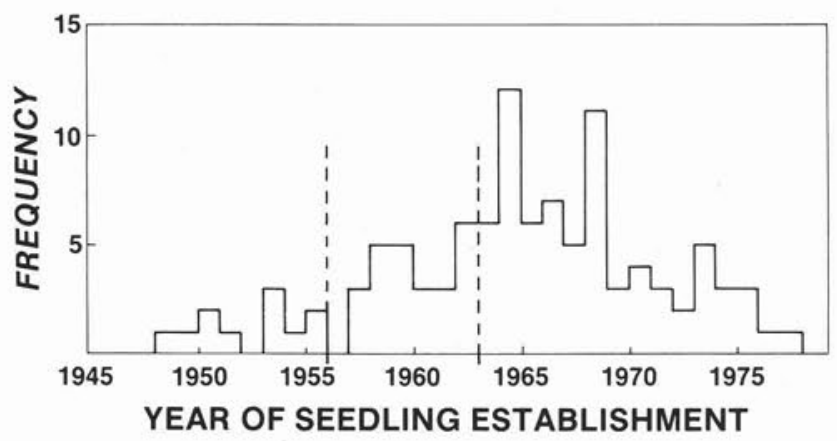

Figure 6. Frequency for all stands combined of established balsam fir seed lings by year. Interval between dotted lines represents the spruce budworm infestation period.

Table 3. Average numbers of balsam fir seedlings by establishment periods.

\begin{tabular}{lcc}
\hline $\begin{array}{l}\text { Period of seedling } \\
\text { establishment }\end{array}$ & $\begin{array}{c}\text { Average no. } \\
\text { seedlings per ha }\end{array}$ & Percent stands \\
\hline Before outbreak only & 3336 & 5 \\
Before and after outbreak & 6647 & 50 \\
After outbreak only & 5387 & 45 \\
\hline
\end{tabular}

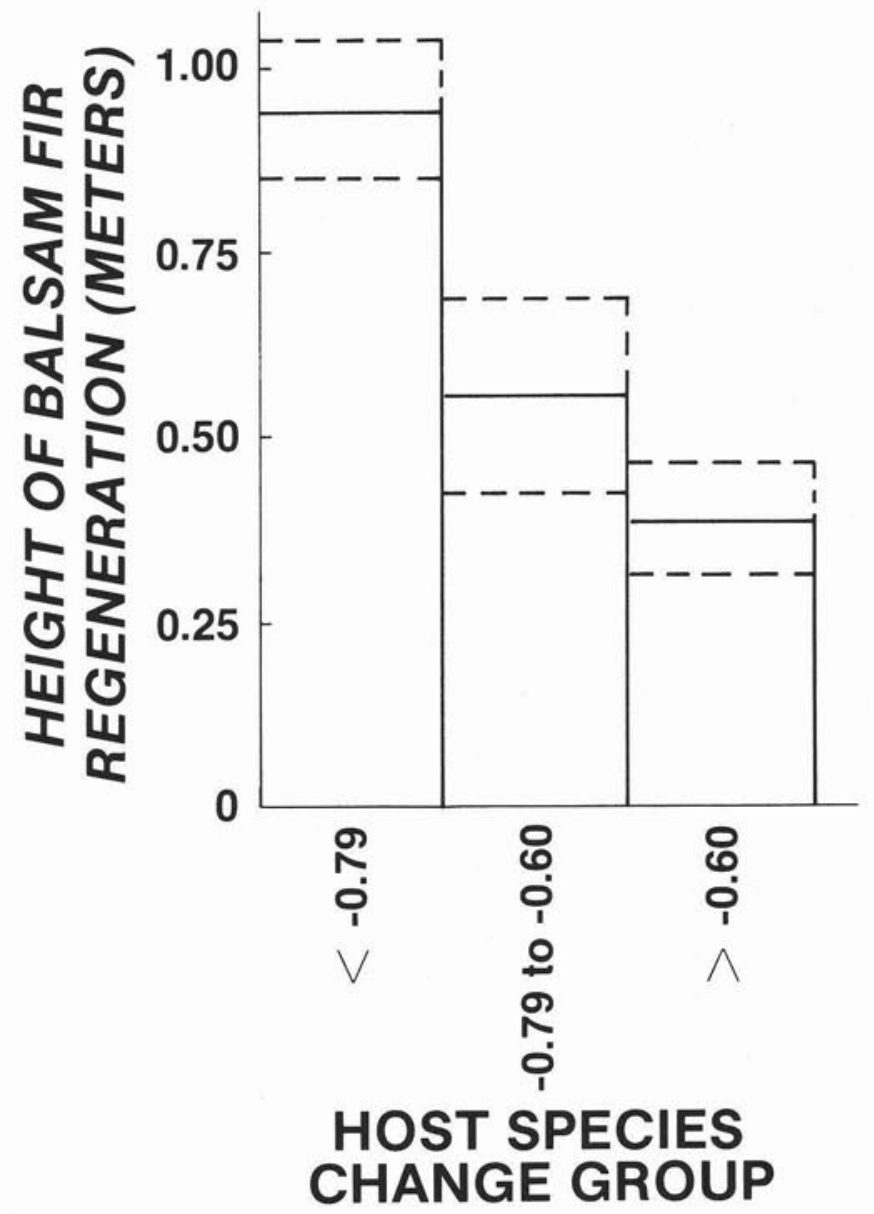

Figure 5. Average height of balsam fir regeneration by overstory host species change group 1979 ba - 1957 ba (e.g. a value

$$
1957 \text { ba }
$$

$<-.79$ indicates the greatest reduction in overstory stocking after the budworm outbreak). Dashed lines indicate limits of one standard error of the mean.

spruce, red maple, aspen, or white birch trees was correlated with abundance of regeneration for the respective species. Red maple was the most frequent hardwood invader followed by white birch and aspen. Shrubs were the principal competitors. Raspberry, hazel, and mountain maple were the mosi abundant shrubs and were found where greatest disturbance to the overstory had occurred. High shrub density was associated with reduced balsam fir regeneration.

Balsam fir regeneration was most abundant where between 20 to $80 \%$ change in stand basal area occurred. Higher or lower levels of change in stand basal area resulted in fewer numbers of balsam fir regeneration. However, high levels of change in overstory density resulted in taller seedlings.

Where the basal area of nonhost species was moderate or higher prior to the budworm attack, the subsequent stands were usually adequately stocked with balsam fir. This may have resulted form better survival of overstory balsam fir trees, which produced seed soon after the outbreak subsided. Where nonhost basal area was high (exceeded $45 \%$ ) shading apparently caused a reduction in the establishment of balsam fir seedlings, but regeneration was still adequate. Greatest numbers of balsam fir seedlings were found in stands where 
they originated both before as well as after the outbreak. Height classes of seedlings that originated before the outbreak were uniformly distributed due to fir's characteristic to persevere through a wide range of suppression levels. White spruce regeneration was low (av. $710 / \mathrm{ha}$ ), it occurred in $66 \%$ of the stands, and only $20 \%$ of the quadrats stocked with this species. Nevertheless, the white spruce seedlings were well established and provide a strong potential for crop tree selection in early cultural work.

\section{References}

Bakuzis, E.V. and H.L. Hansen. 1965. Balsam Fir. Univ. Minn. Press, Minneapolis. $445 p$.

Baskerville, G.L. 1975. Spruce budworm: super silviculturist. For. Chron. 51: 138-140.

Batzer, H.O. 1969. Forest character and vulnerability of balsam fir to spruce budworm in Minnesota. For. Sci. 15: 17-25.

Batzer, H.O. 1973. Net effect of spruce budworm defoliation on mortality and growth of balsam fir. J. For. 71: 34-37.

Batzer, H.O. and A.R. Hastings. 1981. Rating spruce-fir stands for spruce budworm vulnerability in Minnesota. In: Hazard-Rating Systems in Forest Insect Pest Management: Symposium Proc Athens, GA, July 31-Aug. 1, 1980. USDA Forest Serv. Gen. Tech. Rep. WO-27, p. 105-108.

Candy, R.H. 1951. Reproduction on cut-over and burned-over land in Canada. Canada Dept. Res. and Develop., For. Res. Div., Silv. Res. Note 92.224 p.

Craighead, F.C. 1924. Studies on the spruce budworm: Cacoecia fumiferana Clem., Pt. II. General bionomics and possibilities of prevention and control. Dom. Dept. Agr. Bull. No. 37 N.S (teach.).

De Gryse, J.J. 1944. Enemies of the forest - man or insects? Proc Roy. Can. Instit, Ser. III A, Vol. IX. Sess. 1943-1944: 52-62.
Fy, R.E. and J.B. Thomas. 1963. Regeneration of balsam fir and spruce about fifteen years following release by spruce budworm attack. For. Chron. 39: 385-397.

Gevorkiantz, S.R. 1956. Site index curves for balsam fir in the Lake States. USDA Forest Serv., Lake States Forest Exp. Sta. Tech. Note 465, 2 p.

Ghent, A.W. 1958. Studies of vegetation in forest stuands devastated by the spruce budworm. II. Age, height-growth, and related studies of balsam-fir seedlings. For. Sci. 4: 135-146.

Ghent, A.W. 1963. Studies of regeneration in forest stands devastated by the spruce budworm. III. Problems of sampling precision and seedling distribution. For. Sci. 9: 295-310

Ghent, A.W., D.A. Fraser and J.B. Thomas. 1957. Studies of vegetation in forest stands devastated by the spruce budworm. I. Evidence of trends in forest succession during the first decade following budworm devastation. For. Sci. 3: 184-208.

Halvey, J.D. and A.R. Tiedemann. 1978. Effects of defoliation by the Douglas-fir tussock moth on thinning and quantity of streamflow. USDA Forest Serv. Res. Note PNW-326. 13 p.

MacLean, D.A. 1980. Vulnerability of fir-spruce stands during uncontrolled spruce budworm outbreaks: a review and discussion. For. Chron, 56: 213-221.

Prebble, M.L. 1949. Regeneration in budworm devastated stands. For. Ins. Invest. Bi. monthly Prog. Rep., Dom. Dept. Agric. 5(2): 2-3.

Sando, R.W. and D.A. Haines. 1972. Fire weather and behavior of the Little Sioux fire. USDA Forest Serv. Res. Pap. NC-76, 6 p.

Swaine, J.M. 1933. The relation of insect activities to forest development as examplified in the forests of eastern North America. Sci. Agr. 14: 8-31

Vincent, A.B. 1962. Development of balsam-fir thickets in the Green River Watershed following the spruce budworm outbreak of 1913-1919. Canad. Dep. For., For. Res. Br. Tech. Note 119, 20 p.

\section{TIMMERLINN LIMTreE}

PROFESSIONAL AND TECHNICAL SERVICES

IN FORESTRY AND ENVIRONMENTAL SCIENCES

R.R. No. 2, STE. AGATHE DES MONTS, QUE. J8C $2 Z 8$ 